\title{
Clinical Trials on Computer Based Telemedicine: A Systematic Review
}

\author{
Dr. J.U. Weerasinghe BDS, MS, PhD \\ Member, Specialty Board in Biomedical Informatics, Post Graduate Institute of Medicine, University of \\ Colombo, Sri Lanka \\ Senior Lecturer, Faculty of Dental Sciences, University of Peradeniya, Sri Lanka \\ E-mail address: juw@pdn.ac.lk
}

Sri Lanka Journal of Bio-Medical Informatics 2010;1(1):12-20

DOI: 10.4038/sljbmi.v1i1.1481

\begin{abstract}
Introduction

Recent developments in the field of ICT may have an impact on telemedicine. This systematic review aims to evaluate the recent clinical trials of telemedicine in relation to store-and-forward, real time and remote monitoring methods.
\end{abstract}

\section{Method}

Articles were obtained from November 2007 to November 2009 using the MEDLINE database. Studies reported on clinical trials were included and those indicating the use of telephony, electrical equipment and feasibility studies were excluded. Articles were abstracted and grouped for various disciplines for analysis.

\section{Results}

There were three large sample Randomised Control Trials (RCTs), nine small sample RCTs, four prospective studies, three retrospective studies, one cohort study, four case control studies, and fifteen descriptive studies. The three large sample RCTs have been reported one each in neurology, diabetes and dermatology.

Thirty nine articles selected were nine on neurology, four each on psychiatry, diabetes and cardiology, three each on ophthalmology and dermatology, two each on acute care, transplant and ENT and one each on child abuse, endoscopy, general practice, leprosy, nephrology and radiology.

After further exclusion, rest of the 27 articles revealed that the outcome had improved in $41 \%$, comparable in $15 \%$, benefited in $33 \%$ and not enhanced in $11 \%$ when telemedicine was compared to conventional approaches.

Conclusions

Most of studies reported have revealed advantages of telemedicine against conventional methods of care. However further large sample randomized controlled trials are necessary to confirm these results.

Keywords: Telemedicine, Clinical Trials

\section{Introduction}

Telemedicine is the use of information and communication technology to provide health care services to individuals who are at some distance from a selected health care provider ${ }^{(1)}$.

There are three major types of computer based telemedicine applications in terms of how the information is transferred:

a. Store-and-forward method in which recorded data is transferred offline

b. Real time method which involves online two way interactive videoconferencing

c. Remote monitoring method in which patients are monitored at a distance which can either be hospital or home based.

Telemedicine techniques have been adopted for various disciplines such as radiology, dermatology, cardiology, pathology, surgery, psychiatry, neurology, ophthalmology and 
pharmacy $^{(2)}$.

Over the last few years, many aspects of information and communication technology seem to have changed worldwide and that is likely to have made an impact on telemedicine activities. Evidence on the effectiveness of telemedicine when compared to face-to-face care is sparse

(3). Previous reviews on telemedicine have studied assessment methods, cost effectiveness and patient outcomes. In this paper an attempt has been made to review the clinical trials that used telemedicine interventions reported in the scientific literature during the last two years. This study would help to identify the key areas in which computer based telemedicine have been applied successfully recently.

\section{Methods}

Computerized literature searches were performed using the MEDLINE database for articles from November 2007 to November 2009. Inclusion criteria were the key words telemedicine, human, and clinical trial.

Exclusion criteria were the use of telephony, electrical equipment and feasibility studies. Each title and abstract was retrieved and reviewed. Full text articles also were studied where possible. Articles were classified according to the system by Jovell and Navarro-Rubio $(1,4)$ (Table 1), where 9 levels are described in descending order of strength. Articles were then grouped into subsets according to the disciplines and analyzed for their content.

Table 1. Classification of studies (According to Jovell and Navarro-Rubio)

1. Meta analysis of randomized controlled trials (RCT)

2. Large sample randomized controlled trials

3. Small sample randomized controlled trials

4. Nonrandomized controlled prospective studies

5. Nonrandomized controlled retrospective studies

6. Cohort studies

7. Case-control studies

8. Non-controlled clinical series, descriptive studies, consensus methods

9. Anecdotes or case reports

\section{Results}

Literature searching yielded 64 articles. After screening for exclusion criteria, 39 articles were selected for the analysis. Of these, two were on store-and-forward method, twenty eight were on real time video conferencing and nine were on remote monitoring. With regard to the disciplines involved there were nine in neurology, four each in psychiatry, diabetes and cardiology, three each in ophthalmology and dermatology, two each in acute care, transplant and ENT and one each in child abuse, endoscopy, general practice, leprosy, nephrology and radiology. According to Jovell and Navarro-Rubio classification there were three large sample RCTs, nine small sample RCTs, four prospective studies, three retrospective studies, one cohort study, four case control studies, and fifteen descriptive studies. Details of interventions and outcomes of twenty seven studies for each discipline group in descending order of strength are given in Table 2. Rest of the studies representing individual miscellaneous disciplines were excluded. 
Table 2. Details of interventions and outcome of studies

\begin{tabular}{|c|c|c|c|}
\hline \multicolumn{4}{|c|}{ Discipline: Neurology (9 interventions) } \\
\hline Author/Ref & Sample & Intervention & Outcome \\
\hline Meyer $^{(5)} 2007$ & 400 & $\begin{array}{l}\text { telemedicine in the } \\
\text { STRokE DOC trial }\end{array}$ & $\begin{array}{l}\text { It is feasible to perform site-independent } \\
\text { stroke consultations }\end{array}$ \\
\hline Ahmed $^{(6)} 2008$ & 41 & $\begin{array}{l}\text { Epilepsy follow-up care } \\
\text { through telemedicine }\end{array}$ & $\begin{array}{l}\text { Follow-up care of epilepsy patients reduced } \\
\text { patient costs, and improved patient } \\
\text { satisfaction }\end{array}$ \\
\hline $\begin{array}{l}\text { Dallolio }^{(7)} \\
2008\end{array}$ & & $\begin{array}{l}\text { Telerehabilitation in } \\
\text { spinal injury }\end{array}$ & $\begin{array}{l}\text { Benefited patients discharged from a spinal } \\
\text { cord unit compared with standard care }\end{array}$ \\
\hline $\begin{array}{l}\text { Huijgen }^{(8)} \\
2008\end{array}$ & & $\begin{array}{l}\text { Home-based } \\
\text { telerehabilitation stroke, } \\
\text { brain injury and } \mathrm{m} \\
\text { sclerosis. }\end{array}$ & Increased the efficiency of care. \\
\hline Piron ${ }^{(9)} 2009$ & 36 & Telerehabilitation & $\begin{array}{l}\text { Early discharge from hospital was sustained } \\
\text { by a telerehabilitation programme }\end{array}$ \\
\hline $\begin{array}{l}\text { Audebert } \\
2009\end{array}$ & 3060 & $\begin{array}{l}\text { Telemedicine in } \\
\text { community hospitals for } \\
\text { stroke }\end{array}$ & $\begin{array}{l}\text { Telemedicine in community hospitals offers } \\
\text { long-term benefit for acute stroke patients }\end{array}$ \\
\hline $\begin{array}{l}\text { Audebert } \\
2008\end{array}$ & 223 & Mobile teleconsulting & Benefitted remote clinical decision-making \\
\hline Meyer $^{(12)} 2008$ & 234 & $\begin{array}{l}\text { Telemedicine in the } \\
\text { STRokE DOC trial }\end{array}$ & $\begin{array}{l}\text { Telemedicine consultations resulted in more } \\
\text { accurate decision making compared with } \\
\text { telephone }\end{array}$ \\
\hline Lutz $^{(13)} 2009$ & 9 & $\begin{array}{l}\text { Home-telehealth for } \\
\text { recovering from stroke }\end{array}$ & $\begin{array}{l}\text { Innovative ways to target } \\
\text { post-stroke rehabilitation programmes }\end{array}$ \\
\hline \multicolumn{4}{|c|}{ Discipline: Psychiatry (4 interventions) } \\
\hline Author/Ref & Sample & Intervention & Outcome \\
\hline $\begin{array}{l}\text { Kay-Lambkin } \\
\text { (14) } 2009\end{array}$ & 97 & $\begin{array}{l}\text { Computer-based } \\
\text { psychological RX }\end{array}$ & $\begin{array}{l}\text { Results similar to live intervention targeting } \\
\text { both depression and substance }\end{array}$ \\
\hline $\begin{array}{l}\text { Mitchell } \\
2008\end{array}$ & & $\begin{array}{l}\text { Cognitive-behavioural } \\
\text { therapy via telemedicine } \\
\text { versus face-to-face }\end{array}$ & $\begin{array}{l}\text { Both were acceptable to participants and } \\
\text { roughly equivalent in outcome to therapy }\end{array}$ \\
\hline $\begin{array}{l}\text { Kiropoulos } \\
2008\end{array}$ & 86 & $\begin{array}{l}\text { Internet-based CBT for } \\
\text { panic disorder }\end{array}$ & $\begin{array}{l}\text { Found to be comparable face-to-face and } \\
\text { computer-based treatment }\end{array}$ \\
\hline Myers ${ }^{(17)} 2008$ & 387 & $\begin{array}{l}\text { Adolescent } \\
\text { telepsychiatry }\end{array}$ & $\begin{array}{l}\text { Parents were highly satisfied with the care } \\
\text { given for their children }\end{array}$ \\
\hline
\end{tabular}




\begin{tabular}{|c|c|c|c|}
\hline \multicolumn{4}{|c|}{ Discipline: Diabetes (4 interventions) } \\
\hline Author/Ref & Sample & Intervention & Outcome \\
\hline Shea ${ }^{(18)} 2009$ & 1665 & $\begin{array}{l}\text { Telemedicine case } \\
\text { management }\end{array}$ & $\begin{array}{l}\text { Resulted in net improvements in HgbAlc, } \\
\text { LDL-cholesterol and blood pressure levels } \\
\text { over } 5 \text { years in medically underserved } \\
\text { Medicare beneficiaries }\end{array}$ \\
\hline Smith ${ }^{(19)} 2008$ & 633 & $\begin{array}{l}\text { Specialist telemedicine } \\
\text { intervention }\end{array}$ & $\begin{array}{l}\text { Did not significantly enhanced the value of } \\
\text { CCM in primary care }\end{array}$ \\
\hline $\begin{array}{l}\text { Nikkanen }^{(20)} \\
2008\end{array}$ & 101 & Teleconsultation. & $\begin{array}{l}\text { Improved glucose and LDL cholesterol levels } \\
\text { and blood pressure in patients }\end{array}$ \\
\hline $\begin{array}{l}\text { Izquierdo } \\
2009\end{array}$ & 41 & School telemedicine & $\begin{array}{l}\text { Improved diabetes care in grades } \\
\text { kindergarten through eighth grade. }\end{array}$ \\
\hline \multicolumn{4}{|c|}{ Discipline: Cardiology (4 interventions) } \\
\hline Author/Ref & Sample & Intervention & Outcome \\
\hline Scherr $^{(22)} 2009$ & 120 & $\begin{array}{l}\text { Home based } \\
\text { telemonitoring }\end{array}$ & $\begin{array}{l}\text { Telemedical home surveillance group had } \\
\text { reduced hospitalizations }\end{array}$ \\
\hline $\begin{array}{l}\text { Morgan }^{(23)} \\
2008\end{array}$ & & $\begin{array}{l}\text { Home } \\
\text { videoconferencing } \\
\text { following congential } \\
\text { heart disease }\end{array}$ & $\begin{array}{l}\text { Significantly reduced anxiety levels compared } \\
\text { to telephone }\end{array}$ \\
\hline Dowie $^{(24)} 2009$ & 226 & $\begin{array}{l}\text { Paediatric telecardiology } \\
\text { service for district } \\
\text { hospitals }\end{array}$ & Reduced cost \\
\hline $\begin{array}{l}\text { Antonicelli } \\
2008\end{array}$ & & $\begin{array}{l}\text { Home based } \\
\text { telemonitoring }\end{array}$ & $\begin{array}{l}\text { Associated with improvements in the } \\
\text { composite endpoint of mortality and rate of } \\
\text { hospitalizations }\end{array}$ \\
\hline \multicolumn{4}{|c|}{ Discipline: Ophthalmology (3 interventions) } \\
\hline Author/Ref & Sample & Intervention & \\
\hline $\begin{array}{l}\text { Helveston } \\
2008\end{array}$ & 270 & $\begin{array}{l}\text { Diagnosis and } \\
\text { management of } \\
\text { strabismus using } \\
\text { telemedicine }\end{array}$ & $\begin{array}{l}\text { Cases as viewed on telemedicine presented a } \\
\text { true clinical picture. }\end{array}$ \\
\hline $\begin{array}{l}\text { Boucher }^{(27)} \\
2008\end{array}$ & 3050 & $\begin{array}{l}\text { Teleophthalmology } \\
\text { screening project for } \\
\text { diabetic retinopathy }\end{array}$ & $\begin{array}{l}\text { Efficiently lowered barriers to screening and } \\
\text { created new screening opportunities for a } \\
\text { large number of known diabetic individuals } \\
\text { who were lost to the traditional health system. }\end{array}$ \\
\hline $\begin{array}{l}\text { Lorenz } \\
2009\end{array}$ & 1222 & $\begin{array}{l}\text { Telemedical screening } \\
\text { of retinopathyof } \\
\text { prematurity }\end{array}$ & $\begin{array}{l}\text { Showed the potential of a telemedical } \\
\text { screening program. }\end{array}$ \\
\hline
\end{tabular}




\begin{tabular}{|l|l|l|l|}
\hline \multicolumn{2}{|l|}{ Discipline: Dermatology (3 interventions) } \\
\hline Author/Ref & Sample & Intervention & Outcome \\
\hline $\begin{array}{l}\text { Eminović } \\
2009\end{array}$ & 631 & $\begin{array}{l}\text { Teledermatologic } \\
\text { consultation }\end{array}$ & $\begin{array}{l}\text { Reducing referrals to a } \\
\text { dermatologist by 20.7\%. }\end{array}$ \\
\hline $\begin{array}{l}\text { Bergmo } \\
2009\end{array}$ & 98 & $\begin{array}{l}\text { Web-based } \\
\text { consultations parents of } \\
\text { children with atopic } \\
\text { dermatitis }\end{array}$ & $\begin{array}{l}\text { No effect of supplementing traditional } \\
\text { treatment for childhood dermatitis with web- } \\
\text { based consultations. }\end{array}$ \\
\hline $\begin{array}{l}\text { Edison } \\
1008\end{array}$ & 110 & $\begin{array}{l}\text { Store-and-forward } \\
\text { teledermatology }\end{array}$ & $\begin{array}{l}\text { Confidence ratings for Live Interactive and } \\
\text { Store and Forward were both statistically } \\
\text { lower than In-Person examinations }\end{array}$ \\
\hline
\end{tabular}

\section{Neurology}

Studies consisted of one large sample RCT, four small sample RCTs, one prospective trial and three case studies. The STROKE DOC study ${ }^{(5)}$ which was a 5 year, 400 participant trial, comparing two modalities at four remote sites had shown that is feasible to perform siteindependent stroke consultations. Small sample studies ${ }^{(6-9)}$ and the prospective study ${ }^{(10)}$ on tele-rehabilitation revealed increased efficiency of care, early discharge from hospital and long term benefit for stroke patients. Other three case studies ${ }^{(11-13)}$ have presented innovative ways for post rehabilitation programmes.

\section{Psychiatry}

The three retrospective studies ${ }^{(14-16)}$ presenting computer based treatment for psychiatric disorders have shown that the outcome was found to be comparable to that of face-to-face methods. The case descriptive study $^{(17)}$ conducted on adolescent tele-psychiatry has concluded that parents were highly satisfied with the care given to their children.

\section{Diabetes}

The other large sample RCT retrieved in this review ${ }^{(18)}$ was the telemedicine case management on 1665 patients with usual care in older, ethnically diverse, medically underserved patients with diabetes mellitus which had resulted in net improvements in HgbAlc, LDL-cholesterol and blood pressure levels over a 5 year period in a group of medically under-served Medicare beneficiaries. The retrospective trial ${ }^{(19)}$ based on delivering specialty advice did not reveal any reduction in diabetes related costs. Two other descriptive studies $^{(20,21)}$ reported favourable improvement in diabetes care due to by videoconferencing.

\section{Cardiology}

Two prospective studies ${ }^{(22,23)}$ on home based tele-monitoring in cardiac patients have shown that tele-medical home surveillance groups had reduced hospitalizations and significantly reduced anxiety levels compared to the control groups which did not receive the intervention. While a paediatric tele-cardiology service for district hospitals had reduced cost ${ }^{(24)}$, home based tele-monitoring was found to be associated with improvements in the composite endpoint of mortality and rate of hospitalizations ${ }^{(25)}$.

\section{Ophthalmology}

A retrospective study ${ }^{(26)}$ had shown that diagnosis and management of strabismus using telemedicine presented a true clinical picture. Tele-ophthalmology screening studies ${ }^{(27,28)}$ have shown potential benefits. 


\section{Dermatology}

The large sample RCT ${ }^{(29)}$ on 631 subjects on Tele-dermatologic consultations has revealed reduced referrals to a dermatologist by $21 \%$. A small sample RCT ${ }^{(30)}$ using Web-based consultations on parents of children with atopic dermatitis revealed no effect of supplementing traditional treatment for childhood dermatitis. A descriptive study using store-and-forward tele-dermatology reported that confidence ratings for Live Interactive and Store and Forward were statistically lower than In-Person examinations ${ }^{(31)}$.

\section{Summary of outcome of reported telemedicine approaches}

Regarding relationship of outcome between conventional methods and telemedicine approaches, improvements in results were observed in $11(41 \%)$ of the studies, which included three ${ }^{(6,8,9)}$ from neurology, three ${ }^{(18,20,21)}$ from diabetes, all four ${ }^{(22-25)}$ from cardiology and one ${ }^{(29)}$ from dermatology. Comparable results were seen in $4(15 \%)$ studies, which included three ${ }^{(14-16)}$ from psychiatry, and one ${ }^{26}$ from ophthalmology. Benefits to patients were reported in $9(33 \%)$, which included six ${ }^{(1,7,8,10-13)}$ from neurology, one ${ }^{(17)}$ from psychiatry and two ${ }^{(27.28)}$ from ophthalmology. However three studies (11\%) showed that telemedicine approach did not provide an enhanced benefit. They included a study in diabetes where specialist tele-medicine intervention did not augment Chronic Care Model (CCM) in primary care ${ }^{(19)}$ and studies in dermatology where web based consultations had no effect of supplementing traditional treatment of childhood dermatitis. The dermatologists tested were more confident with in-person examinations than tele-dermatology.

\section{Discussion}

Majority of studies published on telemedicine during the last two years have focused on neurology with psychiatry, diabetes and cardiology, in that order, followed by ophthalmology and dermatology.

Neurology studies which included five RCTs show the usefulness of telemedicine in this discipline. These have been applied in fields of stroke, epilepsy and rehabilitation. In Psychiatry, studies were small sample descriptive in nature and hence the outcome may have not been represented fully. The RCTs performed in diabetes have indicated a promising use of telemedicine for needy patients however a small study had reported negative results. All studies in cardiology have indicated successful implementation of home based surveillance. Retrospective studies on ophthalmology have shown advantages of tele-ophthalmology screening. The RCTs carried out in dermatology revealed advantages but a small sample study has reported some disadvantages of tele-medical systems over in-person examination. This agrees with previous recommendation that large scale RCTs are necessary in identifying health outcomes ${ }^{(3)}$.

\section{Conclusions}

This review shows that most of the large sample high-end studies have confirmed advantages of telemedicine systems whereas small sample low-end studies have found it to be disadvantageous. It is necessary to perform further large sample randomized controlled trials on telemedicine interventions in all health related disciplines to confirm these results. 


\section{References}

1. Roine R, Ohinmaa A, Hailey D. Assessing telemedicine: a systematic review of the literature. CMAJ. 2001; 165-6: 765-71

2. Hoyt R, Sutton M, Yoshihashi A. Medical Informatics Practical Guide for Healthcare Professionals. USA, 2007. ISBN-13:978-1-4303-2162-0

3. Hersh WR, Helfand M, Wallace J, Kraemer D, Patterson P, et al. Outcomes resulting from telemedicine interventions: a systematic review. BMC Medical Informatics and Decision Making. 2001;1:5.

4. Jovell AJ, Navarro-Rubio MD. Evaluation of scientific evidence. Medicina Clínica. 1995;105:740-3.

5. Meyer BC, Raman R, Rao R, Fellman RD, Beer J, et al. The STRokE DOC trial technique: 'video clip, drip, and/or ship'. International Journal of Stroke. 2007;2:2817.

6. Ahmed SN, Mann C, Sinclair DB, Heino A, Iskiw B, et al. Feasibility of epilepsy follow-up care through telemedicine: a pilot study on the patient's perspective. Epilepsia. 2008;49:573-85.

7. Dallolio L, Menarini M, China S, Ventura M, Stainthorpe A, et al. Functional and clinical outcomes of telemedicine in patients with spinal cord injury. Archives of Physical Medicine and Rehabilitation. 2008;89:2332-41.

8. Huijgen BC, Vollenbroek-Hutten MM, Zampolini M, Opisso E, Bernabeu M, et al. Feasibility of a home-based telerehabilitation system compared to usual care: arm/hand function in patients with stroke, traumatic brain injury and multiple sclerosis. Journal of Telemedicine and Telecare. 2008;14:249-56.

9. Piron L, Turolla A, Agostini M, Zucconi C, Cortese F, et al. Exercises for paretic upper limb after stroke: a combined virtual-reality and telemedicine approach. Journal of Rehabilitation Medicine. 2009;41:1016-102.

10. Audebert HJ, Schultes K, Tietz V, Heuschmann PU, Bogdahn U, et al. Long-term effects of specialized stroke care with telemedicine support in community hospitals on behalf of the Telemedical Project for Integrative Stroke Care (TEMPiS). Stroke. 2009;40:902-8.

11. Audebert HJ, Boy S, Jankovits R, Pilz P, Klucken J, et al. Is mobile teleconsulting equivalent to hospital-based telestroke services? Stroke. 2008;39:3427-30.

12. Meyer BC, Raman R, Hemmen T, Obler R, Zivin JA, et al. The STRokE DOC trial technique: 'video clip, drip, and/or ship'. Lancet Neurology. 2008;7:787-95.

13. Lutz BJ, Chumbler NR, Lyles T, Hoffman N, Kobb R. Testing a home-telehealth programme for US veterans recovering from stroke and their family caregivers. Disability and Rehabilitation. 2009;31:402-9.

14. Kay-Lambkin FJ, Baker AL, Lewin TJ, Carr VJ. Computer-based psychological treatment for comorbid depression and problematic alcohol and/or cannabis use: a randomized controlled trial of clinical efficacy. Addiction. 2009;104:378-88.

15. Mitchell JE, Crosby RD, Wonderlich SA, Crow S, Lancaster K, et al. Infection, rejection, and hospitalizations in transplant recipients using telehealth. Behaviour Research Therapy. 2008;46:581-92. 
16. Kiropoulos LA, Klein B, Austin DW, Gilson K, Pier C, et al. Is internet-based CBT for panic disorder and agoraphobia as effective as face-to-face CBT? Journal of Anxiety Disorders. 2008;22:1273-84.

17. Myers KM, Valentine JM, Melzer SM. Child and adolescent telepsychiatry: utilization and satisfaction. Telemedicine Journal and eHealth. 2008;14:131-7.

18. Shea S, Weinstock RS, Teresi JA, Palmas W, Starren J, et al. A randomized trial comparing telemedicine case management with usual care in older, ethnically diverse, medically underserved patients with diabetes mellitus: 5 year results of the IDEATel study. Journal of the American Medical Informatics Association. 2009;16:446-56.

19. Smith SA, Shah ND, Bryant SC, Christianson TJ, Bjornsen SS, et al. Chronic care model and shared care in diabetes: randomized trial of an electronic decision support system. Mayo Clinic Proceedings. 2008;83:747-57.

20. Nikkanen T, Timonen M, Ylitalo K, Timonen O, Keinänen-Kiukaanniemi S, Quality of diabetes care among patients managed by teleconsultation. Journal of Telemedicine and Telecare. 2008;14:295-9.

21. Izquierdo R, Morin PC, Bratt K, Moreau Z, Meyer S, et al. School-centered telemedicine for children with type 1 diabetes mellitus. Journal of Pediatrics. 2009;155:374-9.

22. Scherr D, Kastner P, Kollmann A, Hallas A, Auer J, et al. Effect of home-based telemonitoring using mobile phone technology on the outcome Journal of Medical Internet Research. 2009;11:e34.

23. Morgan GJ, Craig B, Grant B, Sands A, Doherty N, et al. Home videoconferencing for patients with severe congential heart disease following discharge. Congenital Heart Disease. 2008;3:317-24.

24. Dowie R, Mistry H, Rigby M, Young TA, Weatherburn G, et al. A paediatric telecardiology service for district hospitals in south-east England: Archives of Disease in Childhood. 2009;94:273-7.

25. Antonicelli R, Testarmata P, Spazzafumo L, Gagliardi C, Bilo G, et al. Impact of telemonitoring at home on the management of elderly patients with congestive heart failure. J Telemedicine and Telecare. 2008;14:300-5.

26. Helveston EM, Neely DE, Cherwek DH, Smallwood LM. Diagnosis and management of strabismus using telemedicine. Telemed Journal and eHealth. 2008;14:531-8.

27. Boucher MC, Desroches G, Garcia-Salinas R, Kherani A, Maberley D, et al. Teleophthalmology screening for diabetic retinopathy through mobile imaging units within Canada. Can J Ophthalmol. 2008;43:658-68.

28. Lorenz B, Spasovska K, Elflein H, Schneider N. Wide-field digital imaging based telemedicine for screening for acute retinopathy of prematurity (ROP). Six-year results of a multicentre field study. Graefe's Archive for Clinical and Experimental Ophthalmology. 2009;247:1251-62.

29. Eminović N, de Keizer NF, Wyatt JC, ter Riet G, Peek N, et al. Teledermatologic consultation and reduction in referrals to dermatologists: a cluster randomized controlled trial. Archives of Dermatology. 2009;145:558-64.

30. Bergmo TS, Wangberg SC, Schopf TR, Solvoll T. Web-based consultations for parents of children with atopic dermatitis: results of a randomized controlled trial. 
Acta Paediatrica. 2009;98:316-20.

31. Edison KE, Ward DS, Dyer JA, Lane W, Chance L, et al. Diagnosis, diagnostic confidence, and management concordance in live-interactive and store-and-forward teledermatology compared to in-person examination. Telemedicine Journal and eHealth. 2008;14:889-95. 